Tucmeanu A.I. ${ }^{1}$, Popescu Delia Mioara1, Ionescu Elena Valentina ${ }^{2,3}$, Oprea Carmen ${ }^{2,3}$, Mociu A. ${ }^{4}$, Iliescu Mădălina Gabriela ${ }^{3,5}$

\title{
Increasing the quality of health management in Romania through specific consulitancy services
}

1 "Valahia" University of Târgoviște

${ }^{2}$ Techirghiol Balneal and Recovery Sanatorium

${ }^{3}$ Faculty of Medicine, "Ovidius" University of Constanța

${ }^{4}$ Ovidius Clinical Hospital

${ }^{5}$ Rehabilitation Hospital of Eforie Nord

\begin{abstract}
Health management consultancy has become an important source of innovation in management, a bridge between the academic environment, companies and opinion-makers in the field. The objective of this work is to identify the success factors of a consultancy mission within the health system, with the proposal of direct investigation of the hypothesis regarding the positive association between the success of consultancy missions and the consultant's professional integrity. The survey was carried out during January and February 2017, in Bucharest health units, by applying questionnaires to 68 managers both in the public and private system. The analyzed parameters were: the consultant's professional integrity, the consultant's competency, the relations with the consultant, the correct definition of the mission, available financial resources, term observance, and related costs. The information obtained was statistically processed using the SPSS system. The answer options to the items in the questionnaire allowed statistical correlations, verifying the survey hypothesis regarding the association between success and professional
\end{abstract}

Elena V. Ionescu, Mădălina G. Iliescu

Faculty of Medicine, Univeristy „Ovidius” of Constanta

Universitatii Alee No. 1, Campus B

Constanta, Romania

email : elena ionescu@yahoo.com email : iliescumadalina@gmail.com integrity. Any consultancy mission entails negotiation skills from the consultant, as well as an open attitude, listening and communications skills. The environment created by the manager can even further influence the change acceptance.

Key words: health, success, consultant

\section{Introduction}

Health management consultancy has become an important source of innovation in management, a bridge between the academic environment, companies and opinion-makers in the field. Therefore, management consultancy companies use a variety of tools and techniques to approach the various specific issues. Currently, the industry of consultancy includes two large categories of consultancy, namely strategic consultancy and operational consultancy, both referring to the support of organizations in improving performances through the analysis of existing issues and the development of future plans [1]. The offer of consultancy services dedicated to the health system is little represented in Romania, compared to other EU countries, currently only a few consultancy companies dedicated to the health system existing and professionally marketing the service offer. 
The objective of this work is to identify the success factors of a consultancy mission in the health system, and the direct investigation of the hypothesis regarding the positive association between the success of consultancy missions and the consultant's professional integrity.

\section{Material and method}

In order to achieve the objective proposed and verify the hypothesis, a direct analysis was made, regarding the managers in the two sectors of activity, public and private, using specific questionnaires $[2,3]$. The survey was carried out during January and February 2017, in health facilities in Bucharest, with 68 managers, $79.4 \%$ from the public system and $20.6 \%$ from the private system. The analyzed parameters were: the consultant's professional integrity, the consultant's competency, the relations with the consultant, the correct definition of the mission, available financial resources, term observance, related costs [4,5] and the information obtained was statistically processed using the SPSS system.

\section{Results and discussions}

As regards the consultant's professional integrity, we can see that managers believe this matter to be important $-5.9 \%$ and highly important $94.1 \%$ (Figure 1). The consultant's competency in the managers' opinion (Figure 2) is seen as the key factor of success by all respondents in the survey.

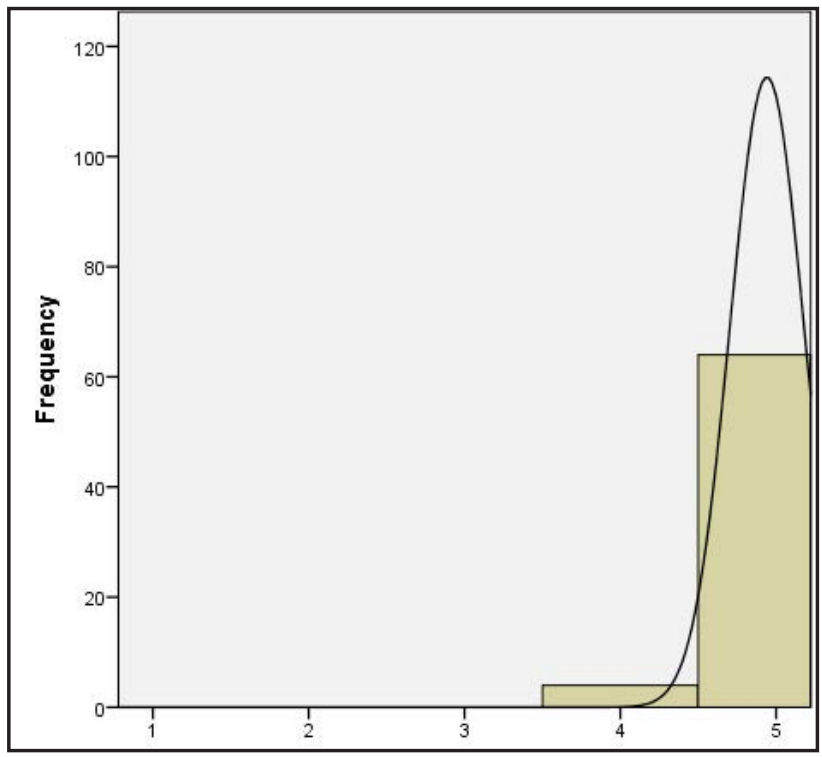

Figure 1. Consultant's professional integrity

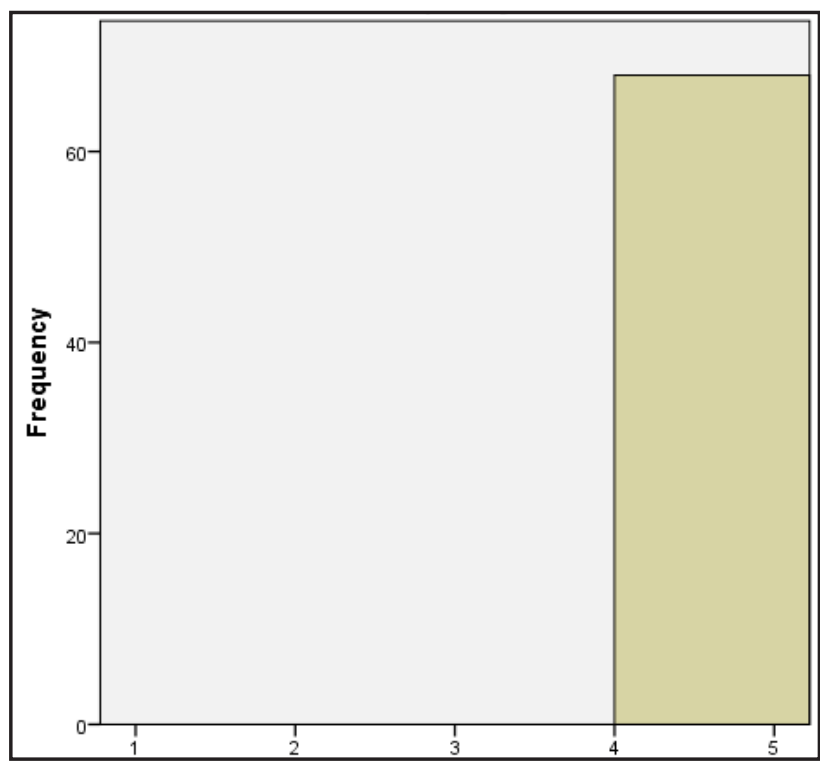

Figure 2. Consultant's competency

As regards the collaboration with the consultant, we can see that managers believe this matter to be important $-79.4 \%$, while as little as $5.9 \%$ do not see the collaboration relation as a success factor (Figure $3)$.

The correct definition of the consultancy mission in the managers' opinion, as we can see in the distribution of answers (Figure 4), influences the success of a consultancy mission to a large - $10.3 \%$ 
and very large extent $-89.7 \%$.

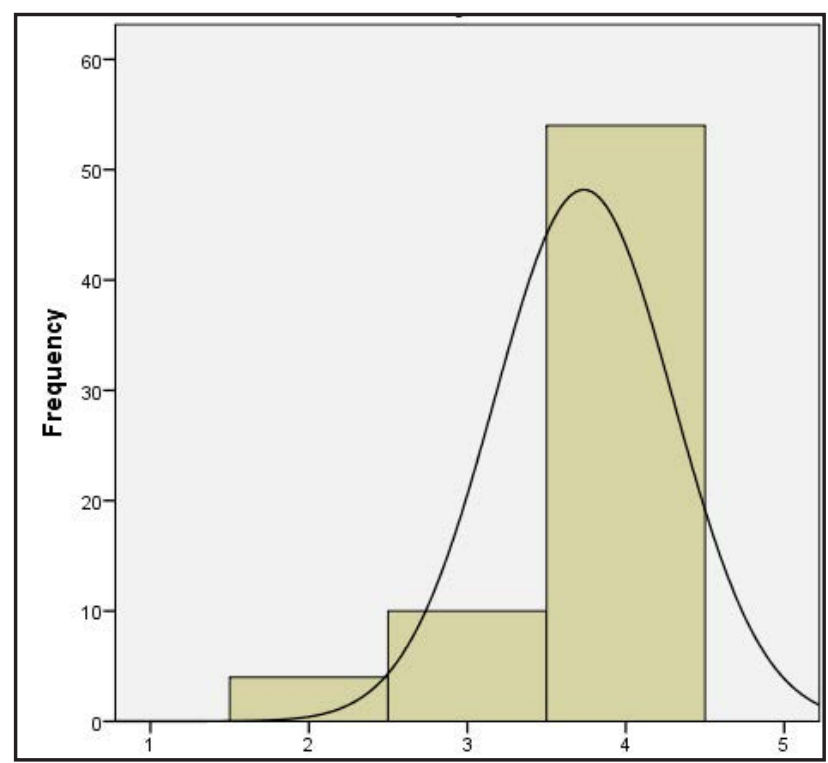

Figure 3. Relations with the consultant

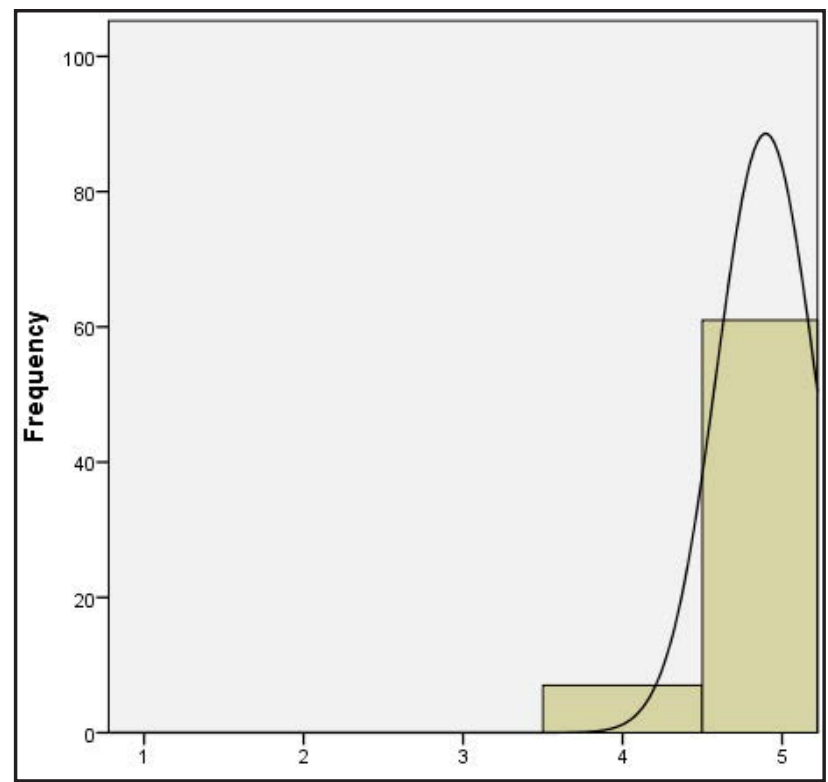

Figure 4. Correct definition of the mission

The financial resources available, in the managers' opinion and as it can be seen in the distribution of the answers (Figure 5), are seen as key factors of the consultancy mission success by all participants to the survey.

Observing the terms, in the managers' opinion and as we can see in the distribution of answers (Figure
6), influences the success of a consultancy mission to a large $-95.6 \%$ and very large extent $-4.4 \%$.

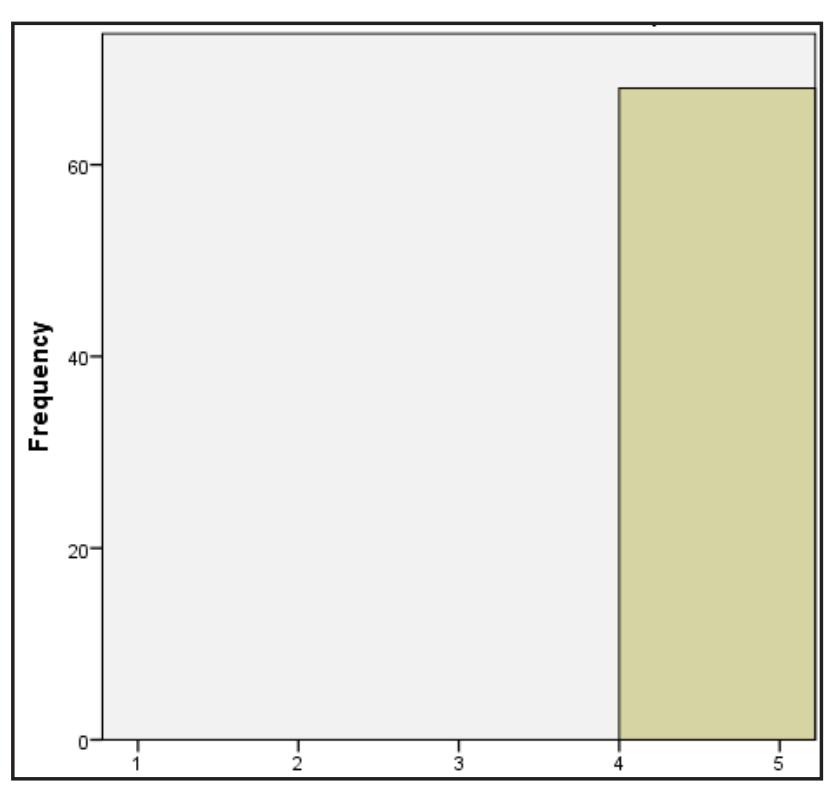

Figure 5 Available financial resources

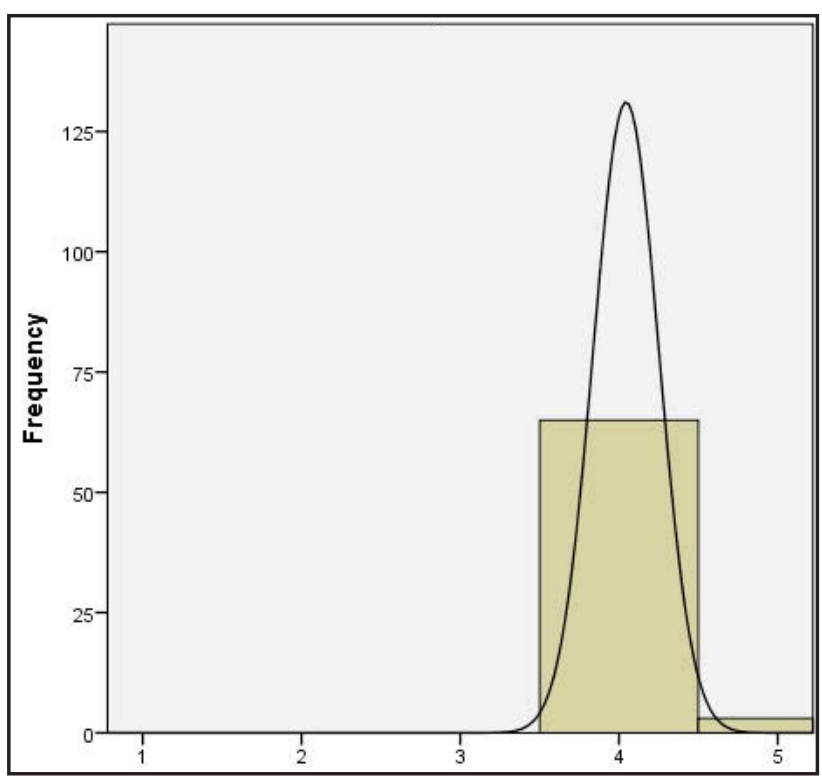

Figure 6. Observance of terms

The cost of consultancy services, in the managers' opinion and as it can be seen in the distribution of the answers (Figure 7), is seen as a key factor of the consultancy mission success by all participants to the survey. 


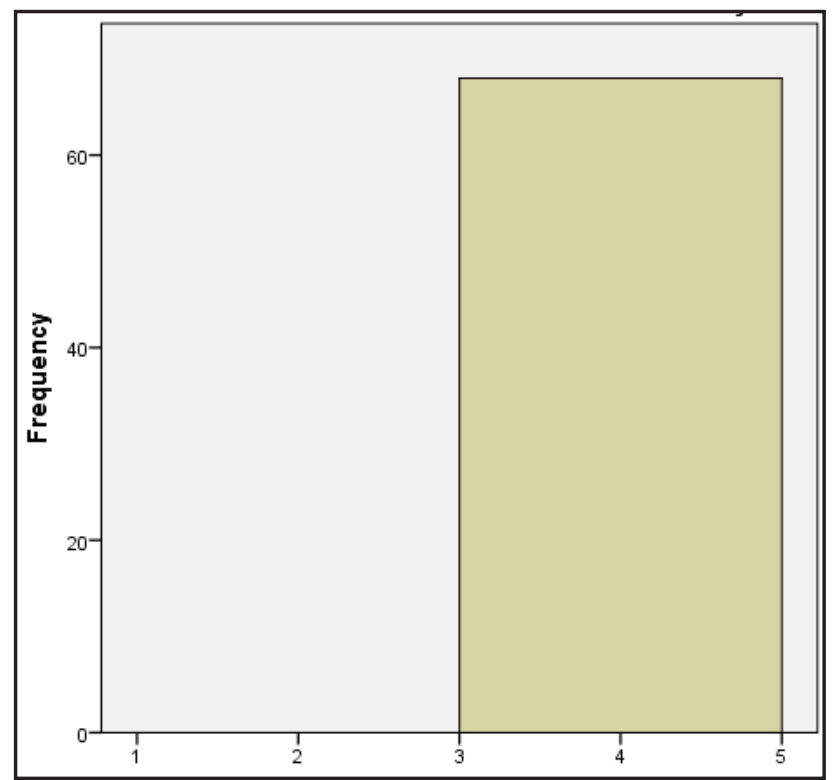

Figure 7. Cost of consultancy services

The direct investigation of the hypothesis regarding the positive association between the success of consultancy missions and the consultant's professional integrity was carried out through statistical processing entailing the linear correlation (the Pearson index) of the two variables: success and professional integrity. The value $r=0.885$ was obtained (Table I), which indicates the existence of a direct strong correlation between the two variables.

Table I. Correlation between success and professional integrity variables

\begin{tabular}{|l|l|c|c|}
\hline \multicolumn{2}{|c|}{} & Success & $\begin{array}{c}\text { Consultant's } \\
\text { professional } \\
\text { integrity }\end{array}$ \\
\hline \multirow{4}{*}{ Success } & $\begin{array}{l}\text { Pearson } \\
\text { Correlation }\end{array}$ & 1 & .885 \\
\cline { 2 - 4 } & Sig. (2-tailed) & & .000 \\
\cline { 2 - 4 } & $\mathrm{N}$ & 68 & 68 \\
\hline \multirow{2}{*}{$\begin{array}{l}\text { Consultant's } \\
\text { professional } \\
\text { integrity }\end{array}$} & $\begin{array}{l}\text { Pearson } \\
\text { Correlation }\end{array}$ & .885 & 1 \\
\cline { 2 - 4 } & Sig. (2-tailed) & .000 & \\
\cline { 2 - 4 } & $\mathrm{N}$ & 68 & 68 \\
\hline
\end{tabular}

\section{Conclusions}

The fast and substantial changes in the Romanian health system require multidimensional consultancy missions in the meaning that the consultant becomes a forerunner of change, on one hand and a change companion and facilitator, on the other hand. The consultant in change management defines, manages and coordinates the communication, training and information activities to support health facilities in any organizational transformation of in their operation (the reorganization of services, implementation of a new IT application production, a new geographical location, etc.) [6]. The consultancy mission involves several stages: first, the natural and required evolution of the health organization, its structure and organization is analyzed; secondly, the impact of the change evolution in the respective organization is measured. Thirdly, the necessary measures accompanying the change must be defined, in terms of labor organization, communication, recruitment, training, etc. This mission is based on the dialogue with managers and the persons working in the operational area. The positive effects of the consultancy mission can many times be unbalanced by some confusion in the health organization operation. The management stepping out of the daily routine must be achieved in an orderly fashion, to avoid the consultant becoming an undesired element in the organization. From this perspective, we outline that any consultancy mission entails negotiation skills from the consultant, as well as an open attitude, listening and communications skills [7]. Prior to using management consultants, the manager should know the extent to which employees could oppose the possible changes, given that the consultant cannot replace the manager's role. It should communicate the changes at the middle-management level, a category standing at the basis of the link between executives and employees, within the introduction and implementation of change. Within the process, the middle manager is the person coping with the employees' fears and uncertainties regarding change. The manager created environment can even further 
influence the change acceptance $[8,9,10]$.

\section{References}

1. 1. Blaikie, N. (1995). Approaches to Social Enquiry. Cambridge, Blackwell, p. 177.

2. 2. Schein, Edgar H. (1999). Process Consultation Revisited: building the helping relationship, Addison- Westley, pp. 241-246.

3. 3. Nees, D.B. \& Greiner, L.E. (1985). Seeing Behind The Look-Alike Management Consultants, Organizational Dynamics, Winter, pp. $68-79$.

4. 4. Adair, J. (2007). Leadership for Information: How to Organize Team Creativity and Harvest Ideas. Kogan Page Limited, pp. 112-114 (2007).

5. 5. Meriläinen, S., Janne, T., Robyn, T. \& Annette, D. (2004). Management Consultant Talk: Cultural Comparison of Normalizving Discourse and Resistance. Human Relations, 11(4): 543.

6. 6. Nicolas, B. (2011). L'hôpital sous pression. Paris, La Découverte.

7. 7. Lindhart, D. (2015). La comédie humaine du travail: de la déshumanisation taylorienne à la sur-humanisation managérial. Editions Eres.

8. 8. Hawkins, P. \& Smith, N. (2006). Coaching, Mentoring \& Organizational Consultancy: Supervision \& Development. Open University Press, Maidenhead, England: 36-37, 193-194.

9. 9. Oprea, C., Armean, P., Stanciu, E., Covaleov, A.E., Iliescu,M.G., Minea, M., Calota, N. \& Ionescu, E.V. (2015). The monitoring and evaluation of work satisfaction in rehabilitation health care. management in health, Management in health, 19(3), 29-31.

10. 10. Oprea, C., Armean, P., Calota, N., Almasan, R. E., Ionescu, E.V. \& Iliescu, M.G. (2017). Considerations regarding the quality of rehabilitation and physical medicine services from patients perspective. Ars Medica Tomitana, l(23), 5-12. 